\title{
Polymorphic mutations in mouse mitochondrial DNA regulate a tumor phenotype
}

Gaku Takibuchi ${ }^{1}$, Hirotake Imanishi ${ }^{1,2,3}$, Mami Morimoto ${ }^{1}$, Kaori Ishikawa ${ }^{1}$, Kazuto Nakada $^{1,4}$, Noriko Toyama-Sorimachi ${ }^{3}$, Yoshiaki Kikkawa ${ }^{5}$, Keizo Takenaga ${ }^{6}$ and Jun-Ichi Hayashi ${ }^{1,4}$

${ }^{1}$ Faculty of Life and Environmental Sciences, University of Tsukuba, 1-1-1 Tennodai, Tsukuba, Ibaraki 305-8572, Japan.

${ }^{2}$ Japan Society for the Promotion of Science (JSPS), 8 Ichiban-cho, Chiyoda-ku, Tokyo 102-8472, Japan.

${ }^{3}$ Department of Molecular Immunology and Inflammation, Research Institute, National Center for Global Health and Medicine, 1-21-1 Toyama, Shinjuku-ku, Tokyo 162-8655, Japan.

${ }^{4}$ International Institute for Integrative Sleep Medicine (WPI-IIIS), University of Tsukuba, 1-1-1 Tennodai, Tsukuba, Ibaraki 305-8572, Japan.

${ }^{5}$ Mammalian Genetics Project, Tokyo Metropolitan Institute of Medical Science, 2-1-6 Kami-kitazawa, Setagaya-ku, Tokyo, 156-8506, Japan.

${ }^{6}$ Department of Life Science, Shimane University Faculty of Medicine, 89-1 Enya-cho, Izumo, Shimane 693-8501, Japan.

Corresponding author :

Graduate School of Life and Environmental Sciences, Institute of Biological Sciences, University of Tsukuba, 1-1-1 Tennoudai, Tsukuba, Ibaraki 305-8572, Japan.

Tel/Fax: +81 298536650; E-mail: jih45@biol.tsukuba.ac.jp (J.-I. Hayashi). 


\section{ABSTRACT}

To examine whether polymorphic mtDNA mutations that do not induce significant respiration defects regulate phenotypes of tumor cells, we used mouse transmitochondrial tumor cells (cybrids) with nuclear DNA from C57BL/6 (B6) strain and mtDNA from allogenic C3H strain. The results showed that polymorphic mutations of $\mathrm{C} 3 \mathrm{H}$ mtDNA in the cybrids induced hypoxia sensitivity, resulting in a delay of tumor formation on their subcutaneous inoculation into B6 mice. Therefore, the effects of polymorphic mutations in normal mtDNA have to be carefully considered, particularly when we apply the gene therapy to the embryos to replace their pathogenic mtDNA by normal mtDNA.

Key words: Transmitochondrial cybrids; Mouse $\mathrm{C} 3 \mathrm{H}$ mtDNA; Polymorphic mtDNA mutations; Tumor phenotypes; Hypoxia sensitivity

\section{INTRODUCTION}

Accumulation of the mtDNA with pathogenic mutations that induce significant mitochondrial respiration defects can be responsible for mitochondrial diseases (Wallace, 2005; Taylor and Turnbull, 2005), and is involved in aging and age-associated disorders (Jacobs, 2003; Loeb et al., 2005; Taylor and Turnbull 2005; Wallace, 2005; Khrapko and Vija, 2008). Moreover, accumulation of somatic mutations in mtDNA with age can also be involved in tumor development, since some of the somatic mtDNA mutations induce mitochondrial respiration defects, resulting in upregulation of aerobic glycolysis (the Warburg effects) (Taylor and Turnbull 2005; Wallace, 2005). Our previous studies showed that specific mtDNA mutations regulate tumor phenotypes as a consequence of overproduction of the reactive oxygen species 
(ROS) and the resultant induction of genetic instability (Ishikawa et al., 2008; Imanishi et al., 2011; Hashizume et al., 2012).

As animal models for these mtDNA-based disorders, our previous studies generated transmitochondrial mito-mice $\Delta$ carrying mtDNA with a pathogenic deletion mutation ( $\Delta$ mtDNA) (Inoue et al., 2000; Nakada et al., 2001), and succeeded in generation of their healthy progeny via nuclear transplantation from one-cell embryos into enucleated oocytes with normal mtDNA (Sato et al., 2005). Subsequently, the nuclear transplantation was applied in primate (Tachibana et al., 2009) and human embryos (Craven et al., 2010; Tachibana et al., 2013; Paull et al., 2013). However, one of the most important problems that have to be solved before applying the nuclear transplantation technology to human cases is the influence of polymorphic mutations in normal mtDNA from the oocyte donors on the phenotypes of the progeny, even when the polymorphic mtDNA mutations do not induce significant respiration defects. In fact, some polymorphic mutations in mouse mtDNA were proposed to affect on age-related hearing loss (Johnson et al., 2001), learning retardation (Roubertoux et al., 2003), delay of cell proliferation (Moreno-Loshuertos et al., 2006), and defects in behaviour (Sharpley et al., 2012).

Our previous study (Ishikawa et al., 2010) revealed a novel role of polymorphic mutations in mtDNA: innate immune system in C57BL/6 (B6) strain mice can recognize polymorphic mutations in mtDNA from allogenic NZB strain mice, resulting in suppression of tumor formation of transmitochondrial tumor cells with NZB mtDNA (P29mtNZB cybrids) in B6 mice. The P29mtNZB cybrids possessed syngenic B6 strain-derived nuclear DNA from P29 tumor cells but possessed mtDNA from allogenic NZB strain mice. On the contrary, $\mathrm{P} 29 \mathrm{mtC} 3 \mathrm{H}$ cybrids with allogenic $\mathrm{C} 3 \mathrm{H}$ mtDNA were able to form tumors, but showed latency periods to form detectable tumor masses longer than those of P29mtB6 cybrids with syngenic B6 mtDNA. 
This study addressed to the issue of how polymorphic mutations in mtDNA from allogenic $\mathrm{C} 3 \mathrm{H}$ strain induce the delay of tumor formation of $\mathrm{P} 29 \mathrm{mtC} 3 \mathrm{H}$ cybrids under the skin of $\mathrm{B} 6$ mice.

\section{MATERIALS AND METHODS}

\subsection{Cell lines and cell culture.}

Transmitochondrial tumor cybrids $\mathrm{P} 29 \mathrm{mtB} 6$ and $\mathrm{P} 29 \mathrm{mtC} 3 \mathrm{H}$, which were obtained in our previous report (Ishikawa et al., 2010), were grown in normal medium [DMEM + pyruvate $(0.1 \mathrm{mg} / \mathrm{ml})+$ uridine $(50 \mathrm{mg} / \mathrm{ml})+10 \% \mathrm{FBS}]$ in either normoxia $\left(21 \% \mathrm{O}_{2}\right)$ or hypoxia $(7 \%$ $\mathrm{O}_{2}$ ). For treatment with $\mathrm{N}$-acetylcysteine (NAC) (Sigma), cybrids were grown in normal medium supplemented with $20 \mathrm{mM}$ NAC for $48 \mathrm{~h}$.

\subsection{Mouse strains.}

Mice of the inbred strain B6 were obtained from CLEA Japan, Inc. The B6mtC3H mice were generated in our previous study (Kasahara et al., 2006). They showed normal lifespan and no detectable abnormalities (Hashizume et al., 2012). The immunodeficient B6 Rag2 $2^{-/-} / \mathrm{cc}^{-/-}$ mice were provided by S. Koyasu and S. Nagai (Keio University School of Medicine, Shinju-ku, Tokyo, Japan). These mice share B6 nuclear DNA background. The mice were cared for in accordance with the Guide for the Care and Use of Laboratory Animals. Experiments using these mice were approved by the Animal Care and Use Committee of University of Tsukuba and the Research Institute National Center for Global Health and Medicine.

\subsection{Assay of tumor formation and metastasis.}


For testing tumor formation phenotypes, $5 \times 10^{6}$ cells or $5 \times 10^{3}$ cells in $100 \mu \mathrm{l}$ PBS were inoculated subcutaneously into the back of 5-week-old male B6 mice. Maximum (a) and minimum (b) diameters and height (h) of tumors were recorded twice per week. The volume of each tumor (V) was calculated according to the formula: $\mathrm{V}=\pi \mathrm{abh} / 6$. To examine spontaneous metastasis, $5 \times 10^{6}$ cells in $100 \mu \mathrm{l}$ PBS were injected s.c. into the back of 5-week-old male B6 mice. The recipient mice were sacrificed when the tumor volume reached $500 \mathrm{~mm}^{3}$, and their lungs were removed, and then parietal nodules were counted.

\subsection{Estimation of doubling times.}

Growth capacity was determined by plating $1 \times 10^{4}$ cells on 6-well plates in $2 \mathrm{ml}$ of the normal medium, incubated at $37^{\circ} \mathrm{C}$ for 5 days, and performing cell counts at daily intervals.

\subsection{Cell invasion assay.}

The invasive ability of the cells was assayed using cell culture inserts ( $8 \mu \mathrm{m}$ pore size) for 24-well plates coated with Matrigel, according to the manufacturer's instructions (Becton, Dickinson). Total numbers of $2.5 \times 10^{4}$ cells were seeded and incubated for $24 \mathrm{~h}$ at $37^{\circ} \mathrm{C}$. Then, the number of invaded cells on the lower surface of the membrane was counted under a light microscope. Each experiment was performed in triplicate.

\subsection{Cell migration assay.}

The ability of cell migration was detected using non-coated cell culture inserts ( $8 \mu \mathrm{m}$ pore size) for 24-well plates according to the manufacturer's instructions (Becton, Dickinson). For testing cell migration, $1.25 \times 10^{4}$ cells were seeded, and after incubation for $24 \mathrm{~h}$ at $37^{\circ} \mathrm{C}$, the number of migrated cells on the lower surface of the membrane was counted under a light microscope. Each experiment was performed in triplicate.

\subsection{Histological analysis.}


Cytochemical analysis for cytochrome c oxidase (COX) activity was carried out based on the procedures as described previously (Seligman et al., 1968) with slight modifications (Mito et al., 2013).

\subsection{Measurement of mitochondrial ROS.}

Mitochondrial ROS generation was estimated using MitoSOX-Red mitochondrial superoxide indicator (Invitrogen) and Amplex Red Hydrogen Peroxide/Peroxidase Assay kit (Invitrogen). In mitochondrial superoxide measurement, cells were incubated with $5 \mu \mathrm{M}$ MitoSOX-Red for $20 \mathrm{~min}$ at $37^{\circ} \mathrm{C}$ in serum-free DMEM, washed twice with serum-free DMEM, and then immediately analyzed with a FACSCalibur Flow Cytometer (Becton Dickinson). The hydrogen peroxide $\left(\mathrm{H}_{2} \mathrm{O}_{2}\right)$ levels in isolated mitochondria from the cybrids were measured using the HRP-linked fluorometric assay. Isolated mitochondria (10-20 $\mu \mathrm{g}$ in $50 \mu \mathrm{l}$ volume) were added to 96 well plate in triplicates with a total reaction volume of $100 \mu$ of reaction buffer containing $0.1 \mathrm{U} / \mathrm{ml} \mathrm{HRP}$, and $50 \mu \mathrm{M}$ Amplex Red reagents. Fluorescence was measured using a Spectra Max 190 Absorbance Microplate Reader (Molecular Devices) at room temperature. The $\mathrm{H}_{2} \mathrm{O}_{2}$ concentrations were calculated from standard curve and normalized with per mg protein.

\subsection{Measurement of lactate.}

Cells were seeded at $5 \times 10^{4}$ cells/well of a 12 -well plate and cultured for $24 \mathrm{~h}$. The amounts of lactates in the cell medium were estimated using an F-kit L-Lactic acid (Roche, Basel, Switzerland).

\subsection{SDS-PAGE and Western blotting}

Cells were lysed in 1\% Nonidet P-40, $150 \mathrm{mM} \mathrm{NaCl}$, 10\% glycerol, $2 \mathrm{mM}$ EDTA, $20 \mathrm{mM}$ Tris- $\mathrm{HCl}(\mathrm{pH} 8.0), 1 \mathrm{mM}$ dithiothreitol, $1 \mathrm{mM}$ phenylmethylsulfonyl fluoride (PMSF), protease inhibitor mixture (Roche Diagnostics GmbH, Mannheim, Germany) and phosphatase 
inhibitor cocktail (PhosSTOP, Roche) for $20 \mathrm{~min}$ on ice. After centrifugation at 10,000g for 10 min at $4^{\circ} \mathrm{C}$, the supernatants were used for further analyses. Protein concentration in the supernatants was determined by the method of Bradford using bovine serum albumin (BSA) as a standard. Proteins were resolved by SDS-PAGE under reducing conditions and the resolved proteins were transferred electrophoretically to Immobilon-P Transfer Membrane (Merck Millipore, Japan). After incubating with 10\% BSA in TBS-T (150 mM NaCl, $50 \mathrm{mM}$ Tris- $\mathrm{HCl}(\mathrm{pH} 7.4), 0.05 \%$ Tween 20) for at least $1 \mathrm{~h}$ at room temperature, the membrane was incubated with polyclonal antibody for the appropriate time, washed extensively with TBS-T, and then incubated with horseradish peroxidase-conjugated goat anti-rabbit IgG.

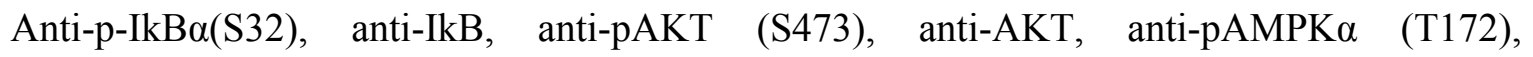
anti-AMPK $\alpha$ and anti-LC3B were obtained from Cell Signaling Technology (Japan), and anti-BCL-2, anti-BCL-X $\mathrm{L}$, anti-MCL-1, anti-BAX, and anti- $\beta$-actin were from Santa Cruz Biotechnology Inc. (Santa Cruz, CA). Anti- $\alpha$-tubulin was obtained from Sigma-Aldrich. Monoclonal anti-HIF-1 $\alpha$ antibody was obtained from Novus Biologicals, Littleton, CO, USA. Proteins were detected using Amersham ECL Western blotting detection reagents (GE Healthcare, Buckinghamshire, UK).

\subsection{Assay of hypoxia viability.}

Hypoxia viability was determined by plating $1 \times 10^{5}$ cells on 6 -well plates in $2 \mathrm{ml}$ of medium and cultured at $37^{\circ} \mathrm{C}$ for 5 days in hypoxic conditions $\left(<0.1 \% \mathrm{O}_{2}\right)$ using an Anaero Pack (SGI, A-07). After incubation, live cells (l) and dead cells (d) were counted using trypan blue. Hypoxia viability (hv) was estimated according to the formula: $h v=1 /(1+d)$

\subsection{Statistical analysis.}

The data were analyzed with a Student's t test. All values are the mean \pm S.D., and $P$ values $<$ 0.05 were considered to be statistically significant. 


\section{RESULTS}

\subsection{Identification of candidate mtDNA mutations inducing a delay of tumor formation.}

First, we confirmed a delay of tumor formation of $\mathrm{P} 29 \mathrm{mtC} 3 \mathrm{H}$ cybrids in $\mathrm{B} 6$ mice using P29mtB6 and P29mtC3H cybrids obtained in our previous study (Ishikawa et al., 2010). The longer latency periods of $\mathrm{P} 29 \mathrm{mtC} 3 \mathrm{H}$ cybrids than those of $\mathrm{P} 29 \mathrm{mtB} 6$ cybrids were emphasized on inoculation of lower numbers of the cybrids into B6 mice (Fig. 1A). Moreover, the latent periods observed on inoculation of $5 \times 10^{6} \mathrm{P} 29 \mathrm{mtC} 3 \mathrm{H}$ cybrids corresponded to those observed on inoculation of $5 \times 10^{3} \mathrm{P} 29 \mathrm{mtB} 6$ cybrids, suggesting the significant suppression of tumor formation of $\mathrm{P} 29 \mathrm{mtC} 3 \mathrm{H}$ cybrids in $\mathrm{B} 6$ mice. On the contrary, no substantial differences between P29mtB6 and P29mtC3H cybrids were observed in tumor growth curves (Fig. 1A). Moreover, both cybrids formed no metastatic nodules in the lungs on their inoculation under the skin of B6 mice. They also showed similar tumor-related phenotypes, such as, doubling times (Fig. 1B), invasion (Fig. 1C), and migration (Fig. 1D) under the culture conditions.

Then, we carried out sequence analysis for determination of mutations in $\mathrm{C} 3 \mathrm{H}$ mtDNA responsible for the delayed tumor formation. Registered mtDNA sequences of $\mathrm{B} 6$ and $\mathrm{C} 3 \mathrm{H}$ strains (Bayona-Bafaluy et al., 2003) revealed that four mutations, which are supposed to be polymorphic, are present in $\mathrm{C} 3 \mathrm{H}$ mtDNA (Table 1). Of the four mutations, one is a missense mutation in the $C O X 3$ (cytochrome $c$ oxidase subunit 3) gene, one is a silent mutation in the ND3 (NADH dehydrogenase subunit 3) gene, and the remaining two are insertion mutations in poly- $\mathrm{T}$ and poly-A tracts of the $t R N A^{A r g}$ gene. However, sequences of $\mathrm{B} 6 \mathrm{mtDNA}$ and $\mathrm{C} 3 \mathrm{H}$ mtDNA in our cybrids may be different from the registered reference sequences (Kasahara et al., 2006). Therefore, we determined the whole mtDNA sequences of the cybrids, and found that mtDNA sequences of $\mathrm{P} 29 \mathrm{mtB} 6$ and $\mathrm{P} 29 \mathrm{mtC} 3 \mathrm{H}$ are slightly different from the registered mtDNA sequences of $\mathrm{B} 6$ and $\mathrm{C} 3 \mathrm{H}$ strains (Table 1): in addition to a missense mutation in the COX3 gene, two missense mutations were present in the ND2 (NADH dehydrogenase subunit 
2) and in the ND5 (NADH dehydrogenase subunit 5) genes, whereas no mutations were detectable in the $t R N A^{A r g}$ gene (Table 1). Thus, the three missense mutations in the COX3, ND2, and ND5 genes can be responsible for the delay of tumor formation of $\mathrm{P} 29 \mathrm{mtC} 3 \mathrm{H}$ cybrids.

\subsection{Effects of the absence of the immune systems in the B6 mice on the latent periods.}

First, we examined the possibility that immune systems in B6 mice are responsible for the delay of tumor formation. Our previous study (Ishikawa et al., 2010) showed that the innate immune system in B6 strain mice could recognize and suppress tumor formation of P29mtNZB cybrids with NZB mtDNA. Thus, the delay of tumor formation of $\mathrm{P} 29 \mathrm{mtC} 3 \mathrm{H}$ cybrids with $\mathrm{C} 3 \mathrm{H}$ mtDNA in $\mathrm{B} 6$ mice also can be caused by innate and/or acquired immune systems of $\mathrm{B} 6$ mice. To test this idea, $\mathrm{P} 29 \mathrm{mtC} 3 \mathrm{H}$ cybrids were inoculated into the $\mathrm{B} 6$ $\operatorname{Rag}^{-/-} / \gamma \mathrm{c}^{-/-}$mice, which are deficient in both acquired and innate immune systems due to deficiency of recombination-activating gene $\left(\operatorname{Rag} 2^{-/}\right)$and the common cytokine receptor gamma chain $\left(\gamma^{--}\right)$, and have no T cells, B cells, natural killer cells, and functional dendritic cells. However, the latent periods of $\mathrm{P} 29 \mathrm{mtC} 3 \mathrm{H}$ cybrids did not change substantially even in the immunodeficient B6 Rag $2^{-/} / \gamma \mathrm{c}^{-/-}$mice (Fig. 2A).

To confirm this idea, $\mathrm{P} 29 \mathrm{mtC} 3 \mathrm{H}$ cybrids were inoculated into $\mathrm{B} 6 \mathrm{mtC} 3 \mathrm{H}$ congenic mice, which possess $\mathrm{B} 6$ nuclear genetic background but possess mtDNA from allogenic $\mathrm{C} 3 \mathrm{H}$ mice. The results showed that the latent periods of tumor formation of $\mathrm{P} 29 \mathrm{mtC} 3 \mathrm{H}$ cybrids did not change substantially, even when the cybrids were injected into $\mathrm{B} 6 \mathrm{mtC} 3 \mathrm{H}$ mice, which share the same nuclear and mitochondrial genomes as those of the cybrids (Fig. 2B). These observations, together with the results shown in Fig. 2A, suggested that the delay of tumor formation of $\mathrm{P} 29 \mathrm{mtC} 3 \mathrm{H}$ cybrids in $\mathrm{B} 6$ mice would not be caused by immunological recognition of polymorphic mutations in $\mathrm{C} 3 \mathrm{H}$ mtDNA, but probably by some abnormalities of mitochondrial respiratory function. 


\subsection{Comparison of respiration-related phenotypes between P29mtB6 and P29mtC3H cybrids.}

Even if the mutations in $\mathrm{C} 3 \mathrm{H}$ mtDNA do not induce detectable respiration defects by biochemical analysis (Ishikawa et al., 2010), some abnormalities related to respiratory functions may be detectable. Therefore, we used P29mtB6 and $\mathrm{P} 29 \mathrm{mtC} 3 \mathrm{H}$ cybrids, and compared respiration-related phenotypes, such as cytochrome $c$ oxidase (COX) activity, ROS and lactate production, and hypoxia sensitivity.

Of the three missense mutations (C4794T in the ND2, G9348A in the COX3, and T12048C in the ND5 genes), one G9348A mutation in the COX3 gene can be a candidate mutation responsible for the delay of tumor formation of $\mathrm{P} 29 \mathrm{mtC} 3 \mathrm{H}$ cybrids, since G9348A mutation occurred in a site highly conserved throughout animals (Table 2). However, cytochemical analysis showed that $\mathrm{COX}$ activity was not reduced in $\mathrm{P} 29 \mathrm{mtC} 3 \mathrm{H}$ cybrids (Fig. 3A). In contrast, overproduction of mitochondrial ROS (superoxide) was observed in $\mathrm{P} 29 \mathrm{mtC} 3 \mathrm{H}$ cybrids (Fig. 3B). Moreover, overproduction of $\operatorname{ROS}\left(\mathrm{H}_{2} \mathrm{O}_{2}\right)$ from mitochondria was confirmed by using mitochondrial fraction from P29mtC3H cybrids (Fig. S1), and thus can be involved in delayed tumor formation in B6 mice (Fig. 1A).

In addition, we examined the possibility that decreased glycolysis of $\mathrm{P} 29 \mathrm{mtC} 3 \mathrm{H}$ cybrids resulted in the delayed tumor formation, since it has been proposed that the Warburg effect (increased glycolysis under normoxia) confers advantage of tumor growth under low $\mathrm{O}_{2}$ condition (hypoxia). In fact, cybrids must survive and start growing under hypoxia on their inoculation under the back skin of B6 mice. Considering that the amounts of lactates reflect glycolytic activity, we estimated them, and found that lactates were not reduced in $\mathrm{P} 29 \mathrm{mtC} 3 \mathrm{H}$ cybrids (Fig. 3C), suggesting that the Warburg effects were not involved in this phenotype.

Another possibility to explain the delayed tumor formation of $\mathrm{P} 29 \mathrm{mtC} 3 \mathrm{H}$ cybrids is that they are sensitive to hypoxia, and require long latent periods to start growing under hypoxia. To examine this possibility we compared the hypoxia survival between $\mathrm{P} 29 \mathrm{mtB} 6$ and $\mathrm{P} 29 \mathrm{mtC} 3 \mathrm{H}$ 
cybrids in hypoxic condition $\left(<0.1 \% \mathrm{O}_{2}\right)$. The results showed that $\mathrm{P} 29 \mathrm{mtC} 3 \mathrm{H}$ cybrids are more sensitive to hypoxia than P29mtB6 cybrids (Fig. 3D). These observations suggest that either ROS overproduction (Fig. 3B and Fig. S1) or hypoxia sensitive phenotype (Fig. 3D) exclusively observed in $\mathrm{P} 29 \mathrm{mtC} 3 \mathrm{H}$ cybrids would be responsible, at least in part, for the delay of tumor formation (Fig. 1A).

\subsection{Effects of the pretreatment of the cybrids with NAC or hypoxia on latent periods.}

To examine the idea that ROS overproduction may result in the delay of tumor formation of P29mtC3H cybrids (Fig. 1A), they were pretreated with N-acetyl cysteine (NAC), one of the antioxidants, to exclude ROS, and then inoculated into B6 mice. As expected, NAC pretreatment reduced the amounts of ROS (Fig. 3B), but did not affect on the latency periods of tumor formation (Fig. 4A). Thus, ROS overproduction would not be involved in expression of the phenotype (Fig. 1A).

Then, we examined another possibility that $\mathrm{P} 29 \mathrm{mtC} 3 \mathrm{H}$ cybrids are sensitive to hypoxia (Fig. 3D), and thus require longer times than P29mtB6 cybrids for hypoxia adaptation. Hypoxic condition $\left(<0.1 \% \mathrm{O}_{2}\right)$ used to examine hypoxia survival (Fig. 3D) is not appropriate for hypoxia adaptation and subsequent inoculation of the cybrids, because the cybrids eventually die in $<0.1 \% \mathrm{O}_{2}$. Therefore, $7 \%$ hypoxia was used for hypoxia adaptation to obtain sufficient number of the adapted cybrids for inoculation. For this, we pretreated the cybrids under 7\% hypoxia for 21 days, which corresponded to the latent periods for tumor formation of P29mtC3H cybrids (Fig. 1A), and then inoculated them under the back skin of B6 mice to test the effect of hypoxia pretreatment on the latent periods. By pretreatment of $\mathrm{P} 29 \mathrm{mtC} 3 \mathrm{H}$ cybrids under the hypoxia for 21 days, their latent periods were changed about 10 days shorter than those of untreated cybrids, while those of P29mtB6 cybrids did not change substantially (Fig. 4B). These observations suggest that some polymorphic mutations in $\mathrm{C} 3 \mathrm{H}$ mtDNA induce a hypoxia sensitive phenotype, resulting in expression of long latent periods to adapt to hypoxic conditions under the skin of B6 mice. 
To examine molecular mechanisms that explain the hypoxia sensitive phenotype of $\mathrm{P} 29 \mathrm{mtC} 3 \mathrm{H}$ cybrids, we compared the expression of the genes related to hypoxia, apoptosis, and autophagy between P29mtB6 and P29mtC3H cybrids. The results showed that enhanced expression of HIF-1 $\alpha$ and phosphorylated AMPK (p-AMPK) was observed in P29mtC3H cybrids (Fig. 5). However, hypoxia adaptation did not suppress enhanced expression of HIF-1 $\alpha$ and p-AMPK (Fig. 5), indicating that it would not directly regulate the delay of tumor formation of $\mathrm{P} 29 \mathrm{mtC} 3 \mathrm{H}$ cybrids (Fig. 1A).

\section{DISCUSSION}

Our previous study (Ishikawa et al., 2010) revealed that polymorphic mutations in mtDNA from allogenic NZB strain mice were recognized by innate immune system in B6 mice, resulting in complete suppression of tumor formation of P29mtNZB cybrids. In contrast, $\mathrm{P} 29 \mathrm{mtC} 3 \mathrm{H}$ cybrids with allogenic $\mathrm{C} 3 \mathrm{H}$ mtDNA were able to form tumors in $\mathrm{B} 6$ mice, although they showed longer latency periods to form detectable tumor masses than those of P29mtB6 cybrids with mtDNA from syngenic B6 strain mice. Because the retarded tumor formation found in $\mathrm{P} 29 \mathrm{mtC} 3 \mathrm{H}$ cybrids is also important as one of the tumor-related phenotypes, this study focused on the mechanisms of the retarded tumor formation observed in $\mathrm{P} 29 \mathrm{mtC} 3 \mathrm{H}$ cybrids.

We identified three missense mutations in $\mathrm{C} 3 \mathrm{H}$ mtDNA by comparison of the whole mtDNA sequences between $\mathrm{P} 29 \mathrm{mtB} 6$ and $\mathrm{P} 29 \mathrm{mtC} 3 \mathrm{H}$ cybrids, and addressed to the issue of how these mutations induce the retardation of tumor formation of $\mathrm{P} 29 \mathrm{mtC} 3 \mathrm{H}$ cybrids in $\mathrm{B} 6$ mice. The results suggested that the retardation was not due to the immunological recognition of $\mathrm{P} 29 \mathrm{mtC} 3 \mathrm{H}$ cybrids by host $\mathrm{B} 6$ immune systems or to ROS overproduction, but to the induction of the sensitivity to hypoxia. Probably, missense mutations in C3H mtDNA (Table 1) induce slight respiration defects that are not sufficient to be detected by our procedures, 
resulting in expression of hypoxia sensitivity and of long periods for $\mathrm{P} 29 \mathrm{mtC} 3 \mathrm{H}$ cybrids to adapt to the hypoxic conditions under the skin of B6 mice. However, the mechanisms of how the $\mathrm{C} 3 \mathrm{H}$ mtDNA mutations induce hypoxia sensitivity and delayed tumor formation are complicated, and we could not at present explain the precise mechanisms.

It has been proposed that polymorphic mutations in poly-A tracts (10A repeats) of the $t R N A^{A r g}$ gene found in the cybrids with mtDNA from NZB strain mice and from NIH3T3 cells induced overproduction of ROS (Moreno-Loshuetros et al., 2006). Although P29mtC3H cybrids with mtDNA from $\mathrm{C} 3 \mathrm{H}$ strain also overproduced ROS, our mtDNA sequence data (Table 1) showed that both mtDNAs from P29mtB6 and P29mtC3H cybrids shared the same poly-A tracts (9A repeats) in the $t R N A^{A r g}$ gene. Moreover, pretreatment of $\mathrm{P} 29 \mathrm{mtC} 3 \mathrm{H}$ cybrids with an antioxidant (NAC) did not affect on the prolonged latent periods for tumor formation (Fig. 4A). Thus, ROS overproduction in $\mathrm{P} 29 \mathrm{mtC} 3 \mathrm{H}$ cybrids would not be caused by mutations in the $t R N A^{A r g}$ gene, and would not be responsible for the delay of tumor formation.

This study revealed that polymorphic mutations in mtDNA affect on a tumor-related phenotype. Involvement of polymorphic mtDNA mutations in expression of tumor phenotypes was proposed based on the evidence that most mtDNA mutations found in tumors were polymorphic mutations (Loeb et al., 2005; Wallace, 2005). Moreover, polymorphic mtDNA mutations were proposed to affect on age-related hearing loss (Johnson et al., 2001), learning retardation (Roubertoux et al., 2003), and a delay of cell proliferation (Moreno-Loshuertos et al., 2006). Furthermore, our previous study (Ishikawa et al., 2010) revealed a novel role of polymorphic mutations in mouse mtDNA by showing that the innate immune system in B6 strain mice can recognize and suppress tumor formation of P29mtNZB cybrids with mtDNA introduced from allogenic NZB strain mice.

Therefore, we have to be careful for polymorphic mutations as well as pathogenic mutations in human mtDNA, particularly when we carry out transplantation of tissues differentiated from iPS cells, and nuclear transplantation to human oocytes for the gene therapy of 
mitochondrial diseases. For example, the mtDNA in iPS cells might accumulate such somatic mutations that can be recognized by innate immune systems or induce hypoxia sensitivity during the aging of the donors, resulting in expression of some unexpected disorders in transplanted tissues. Moreover, one of the most important problems that have to be resolved before applying the nuclear transplantation technology (Craven et al., 2010; Tachibana et al., 2013) to the human oocytes from mothers with mitochondrial diseases is the influence of polymorphic mutations in mtDNA of the oocyte donors on the phenotypes of the progeny, even when the polymorphic mutations do not induce significant respiration defects.

\section{ACKNOWLEDGEMENTS}

This work was supported by Grants-in-Aid for Scientific Research A 25250011 (to J.-I.H.), Scientific Research A 23240058 (to K.N.), and Scientific Research on Innovative Areas 24117503 (to J.-I.H.) from Japan Society for the Promotion of Science. This work was also supported by Grant-in-Aid for JSPS Fellows (to H. I.), and by World Premier International Research Center Initiative (WPI), MEXT, Japan (to K.N. and J.-I.H.).

\section{REFERENCES}

Bayona-Bafaluy, MP., Acín-Pérez, R., Mullikin, JC., Park, JS., Moreno-Loshuertos, R., Hu, P., Pérez-Martos, A., Fernández-Silva, P., Bai, Y., Enríquez, JA., 2003. Revisiting the mouse mitochondrial DNA sequence. Nucleic Acids Res. 31, 5349-5355.

Craven, L., Tuppen, HA., Greggains, GD., Harbottle, SJ., Murphy, JL., Cree, LM., Murdoch, AP., Chinnery, PF., Taylor, RW., Lightowlers, RN., Herbert, M., Turnbull, DM., 2010. Pronuclear transfer in human embryos to prevent transmission of mitochondrial DNA disease. Nature 465, 82-85. 
Hashizume, O., Shimizu, A., Yokota, M., Sugiyama, A., Nakada, K., Miyoshi, H., Itami, M., Ohira, M., Nagase, H., Takenaga, K., Hayashi, J.-I., 2012. Specific mitochondrial DNA mutation in mice regulates diabetes and lymphoma development. Proc. Natl. Acad. Sci. USA $109,10528-10533$.

Imanishi, H., Hattori, K., Wada, R., Ishikawa, K., Fukuda, S., Takenaga, K., Nakada, K., Hayashi, J.-I., 2011. Mitochondrial DNA mutations regulate metastasis of human breast cancer cells. PLoS One. 6, e23401.

Inoue, K., Nakada, K., Ogura, A., Isobe, K., Goto, Y., Nonaka, I., Hayashi, J.-I., 2000. Generation of mice with mitochondrial dysfunction by introducing mouse mtDNA carrying a deletion into zygotes. Nature Genet. 26, 176-181.

Ishikawa, K., Takenaga, K., Akimoto, M., Koshikawa, N., Yamaguchi, A., Imanishi, H., Nakada, K., Honma, Y., Hayashi, J.-I., 2008. ROS-generating mitochondrial DNA mutations can regulate tumor cell metastasis. Science 320, 661-664.

Ishikawa, K., Toyama-Sorimachi, N., Nakada, K., Morimoto, M., Imanishi, H., Yoshizaki, M., Sasawatari, S., Niikura, M., Takenaga, K., Yonekawa, H., Hayashi, J.-I., 2010. The innate immune system in host mice targets cells with allogenic mitochondrial DNA. J. Exp. Med. 207, 2297-2305.

Jacobs, HT., 2003. The mitochondrial theory of aging: dead or alive? Aging Cell 2, 11-17.

Johnson, KR., Zheng, QY., Bykhovskaya, Y., Spirina, O., Fischel-Ghodsian, N., 2001. A nuclear-mitochondrial DNA interaction affecting hearing impairment in mice. Nature Genet. 27, 191-194.

Kasahara, A., Ishikawa, K., Yamaoka, M., Ito, M., Watanabe, N., Akimoto, M., Sato, A., Nakada, K., Endo, H., Suda, Y., Aizawa, S., Hayashi, J.-I., 2006. Generation of 
trans-mitochondrial mice carrying homoplasmic mtDNA with a missense mutation in a structural gene using ES cells. Hum. Mol. Genet. 15, 871-881.

Khrapko, K., Vija, J., 2008. Mitochondrial DNA mutations and aging: devils in the details? Trends in Genet 25, 91-98.

Loeb, LA., Wallace, DC., Martin, GM., 2005. The mitochondrial theory of aging and its relationship to reactive oxygen species damage and somatic mtDNA mutations. Proc Natl Acad Sci USA 102, 18769-18770.

Mito, T., Kikkawa, Y., Shimizu, A., Hashizume, O., Katada, S., Imanishi, H., Ota, A., Kato, Y., Nakada, K., Hayashi, J.-I., 2013. Mitochondrial DNA mutations in mutator mice confer respiration defects and B-cell lymphoma development. PLoS One 8, e55789.

Moreno-Loshuertos, R., Acín-Pérez, R., Fernández-Silva, P., Movilla, N., Pérez-Martos, A., Rodriguez de Cordoba, S., Gallardo, ME., Enríquez, JA., 2006. Differences in reactive oxygen species production explain the phenotypes associated with common mouse mitochondrial DNA variants. Nature Genet. 38, 1261-1268.

Nakada, K., Inoue, K., Ono, T., Isobe, K., Ogura, A., Goto, YI., Nonaka, I., Hayashi, J.-I., 2001. Inter-mitochondrial complementation: mitochondria-specific system preventing mice from expression of disease phenotypes by mutant mtDNA. Nature Med. 7, 934-940.

Paull, D., Emmanuele, V., Weiss, KA., Treff, N., Stewart, L., Hua, H., Zimmer, M., Kahler, DJ., Goland, RS., Noggle, SA., Prosser, R., Hirano, M., Sauer, MV., Egli, D., 2013. Nuclear genome transfer in human oocytes eliminates mitochondrial DNA variants. Nature 493, 632-637.

Roubertoux, PL., Sluyter, F., Carlier, M., Marcet, B., Maarouf-Veray, F., Chérif, C., Marican, C., Arrechi, P., Godin, F., Jamon, M., Verrier, B., Cohen-Salmon, C., 2003. Mitochondrial 
DNA modifies cognition in interaction with the nuclear genome and age in mice. Nature Genet. 35, 65-69.

Sato, A., Kono, T., Nakada, K., Ishikawa, K., Inoue, S., Yonekawa, H., Hayashi, J.-I., 2005. Gene therapy for progeny of mito-mice carrying pathogenic mtDNA by nuclear transplantation. Proc. Natl. Acad. Sci. USA 102, 16765-16770.

Seligman, AM., Karnovsky, MJ., Wasserkrug, HL., Hanker, JS., 1968. Nondroplet ultrastructural demonstration of cytochrome oxidase activity with a polymerizing osmiophilic reagent, diaminobenzidine (DAB). J. Cell Biol. 38, 1-14.

Sharpley, MS., Marciniak, C., Eckel-Mahan, K., McManus, M., Crimi, M., Waymire, K., Lin, C.S., Masubuchi, S., Friend, N., Koike, M., Chalkia, D., MacGregor, G., Sassone-Corsi, P., Wallace, D.C., 2012. Heteroplasmy of mouse mtDNA is genetically unstable and results in altered behavior and cognition. Cell 151, 333-343.

Tachibana, M., Sparman, M., Sritanaudomchai, H., Ma, H., Clepper, L., Woodward, J., Li, Y., Ramsey, C., Kolotushkina, O., Mitalipov, S., 2009. Mitochondrial gene replacement in primate offspring and embryonic stem cells. Nature 461, 367-372.

Tachibana, M., Amato, P., Sparman, M., Woodward, J., Sanchis, DM., Ma, H., Gutierrez, NM., Tippner-Hedges, R., Kang, E., Lee, HS., Ramsey, C., Masterson, K., Battaglia, D., Lee, D., Wu, D., Jensen, J., Patton, P., Gokhale, S., Stouffer, R., Mitalipov, S., 2013. Towards germline gene therapy of inherited mitochondrial diseases. Nature 493, 627-631.

Taylor, RW., Turnbull, DM., 2005. Mitochondrial DNA mutations in human disease. Nat Rev Genet 6, 389-402.

Wallace, DC., 2005. A mitochondrial paradigm of metabolic and degenerative diseases, aging, and cancer: a dawn for evolutionary medicine. Annu. Rev. Genet. 39, 359-407. 


\section{FIGURE LEGENDS}

Fig. 1. Comparison of tumor-related phenotypes between $\mathrm{P} 29 \mathrm{mtB} 6$ and $\mathrm{P} 29 \mathrm{mtC} 3 \mathrm{H}$ cybrids. (A) Tumor formation of the cybrids. Total numbers of $5 \times 10^{6}$ or $5 \times 10^{3}$ cells were inoculated under the back skin of B6 mice. Data are represented as mean values with S.D. $(n=6)$. (B) Doubling times of the cybrids under normal culture condition. Each experiment was performed in triplicate. (C) Cell invasion assay of the cybrids. Total numbers of $2.5 \times 10^{4}$ cells were seeded on the membrane, and the numbers of cells invaded through Matrigel basement membrane extract was counted using a modified Boyden chamber. Each experiment was performed in triplicate. (D) Migration assay of the cybrids. Total numbers of $1.25 \times 10^{4}$ cells were seeded on the membrane, and the number of migrated cells on the lower surface of the membrane was counted under a light microscope. Each experiment was performed in triplicate.

Fig. 2. Effects of absence of the immunological recognitions in the host B6 mice on the latent periods of tumor formation. Total numbers of $5 \times 10^{6}$ cells were inoculated under the skin of (A) $\mathrm{B} 6 \mathrm{Rag} 2^{-/} / \gamma \mathrm{c}^{-/-}$mice, and (B) $\mathrm{B} 6 \mathrm{mtC} 3 \mathrm{H}$ mice to study the involvement of the immune systems in the tumor formation phenotypes of the cybrids $(\mathrm{n}=6)$. The B6 $\mathrm{Rag} 2^{-/-} / \mathrm{\gamma c}^{-/-}$mice are severe combined immunodeficiency models that have macrophages and granulocytes, but no $\mathrm{T}$ cells, B cells, natural killer (NK) cells, or functional dendritic cells (DCs). The $\mathrm{B} 6 \mathrm{mtC} 3 \mathrm{H}$ mice are immunologically identical to $\mathrm{P} 29 \mathrm{mtC} 3 \mathrm{H}$ cybrids in their sharing the same nuclear and mitochondrial genetic backgrounds.

Fig. 3. Comparison of respiration-related phenotypes between $\mathrm{P} 29 \mathrm{mtB} 6$ and $\mathrm{P} 29 \mathrm{mtC} 3 \mathrm{H}$ cybrids. (A) Cytochemical analysis of COX activity. $\rho^{0}$ P29 cells represent mtDNA-less $\left(\rho^{0}\right)$ P29 cells, in which COX staining was not observed due to the absence of mtDNA and the resultant loss of COX activity. Scale bars, $100 \mu \mathrm{m}$. (B) Estimation of ROS (Mitochondrial 
superoxide) levels in the cybrids before and after their pretreatment with an antioxidant $\mathrm{N}$-acetylcysteine (NAC) for $48 \mathrm{~h}$. We used 20mM NAC treatment, since our previous study (Ishikawa et al., 2008) showed that the concentration was sufficient to scavenge ROS and suppress ROS-induced metastasis. Relative ROS levels were expressed as mean fluorescence intensity. Data are represented as mean values with S.D. $(n=3)$. $* P<0.05,{ }^{*} P<0.01$. (C) Estimation of lactate levels in culture medium. Data are represented as mean values with S.D. $(n=3)$. (D) Viability of the cybrids under hypoxia. Sensitivity to hypoxia was determined by cultivation of the cells at $37^{\circ} \mathrm{C}$ for 5 days under hypoxic conditions $\left(<0.1 \% \mathrm{O}_{2}\right)$. Data are represented as mean values with S.D. $(n=3)$. $* P<0.05$, $* * P<0.01$.

Fig. 4. Effects of the pretreatment of the cybrids with NAC or hypoxia on their latent periods for tumor formation. (A) NAC pretreatment. The cybrids were inoculated under the skin of B6 mice after their pretreatment with $20 \mathrm{mM}$ NAC for $48 \mathrm{~h}$, and host B6 mice were furthermore given $60 \mathrm{mM}$ NAC in drinking water ad libitum. (B) Hypoxia pretreatment. The cybrids were inoculated under the skin of B6 mice after their pretreatment with hypoxia for 21 days. The retardation of tumor formation exclusively observed in $\mathrm{P} 29 \mathrm{mtC} 3 \mathrm{H}$ cybrids (Fig. 1A) was improved by their pretreatment with hypoxia but not with NAC.

Fig. 5. Examination of the genes related to the retardation of the tumor formation observed in P29mtC3H cybrids. Western blot analysis was carried out about the genes associated with hypoxia, apoptosis, and autophagy. The gene products associated with hypoxia were examined under normoxia $(\mathrm{N})$, and then those of HIF-1 $\alpha$ and p-AMPK overexpressed in $\mathrm{P} 29 \mathrm{mtC} 3 \mathrm{H}$ cybrids were also examined after hypoxia adaptation under $7 \% \mathrm{O}_{2}$ for 21 days (H).

Fig. S1. $\mathrm{H}_{2} \mathrm{O}_{2}$ concentrations in isolated mitochondria from cybrids. $\mathrm{H}_{2} \mathrm{O}_{2}$ concentrations were calculated from standard curve and normalized with per mg mitochondrial protein. Data are represented as mean values with S.D. $(n=3)$. ${ }^{*} P<0.05$. 
Table 1

Identification of candidate polymorphic mutations in mtDNA inducing a delay of tumor formation in $\mathrm{P} 29 \mathrm{mtC} 3 \mathrm{H}$ cybrids.

\begin{tabular}{|c|c|c|c|c|c|c|c|c|c|}
\hline & Position & $\mathrm{C} 4794 \mathrm{~T}$ & G9348A & T9461C & 9818inst & 9821 insA & $\mathrm{T} 12048 \mathrm{C}$ & 15588 & Accession No. ${ }^{a}$ \\
\hline & Gene & ND2 & $\cos 3$ & ND3 & $t R N A^{A r g}$ & $t R N A^{A r g}$ & ND5 & D-loop & \\
\hline Amino & acid change & $\mathrm{T} 294 \mathrm{I}$ & V248I & Silent & - & - & F103L & - & \\
\hline & C57BL/6J & C & G & $\mathrm{T}$ & $3 \mathrm{~T}$ & $8 \mathrm{~A}$ & $\mathrm{~T}$ & $\mathrm{C}$ & AY1 72335 \\
\hline & C3H / He & $\mathrm{C}$ & A & $\mathrm{C}$ & $4 \mathrm{~T}$ & $9 A$ & $\mathrm{~T}$ & $\mathrm{C}$ & АВ0 49357 \\
\hline & P29mtB6 & $\mathrm{C}$ & G & $\mathrm{C}$ & $3 \mathrm{~T}$ & $9 A$ & $\mathrm{~T}$ & $\mathrm{~T}$ & AP0 13030 \\
\hline & P29mtC3H & $\mathrm{T}$ & $\mathrm{A}$ & $\mathrm{C}$ & $3 \mathrm{~T}$ & $9 A$ & $\mathrm{C}$ & $\mathrm{C}$ & AP013031 \\
\hline
\end{tabular}

${ }^{a}$ Nucleotide sequence data reported are available in DDBJ/EMBL/GeneBank databases under the Database ID: AY172335(C57BL/6J), AB049357(C3H/He), $\mathrm{AP} 013030(\mathrm{P} 29 \mathrm{mtB} 6)$ and $\mathrm{AP} 013031(\mathrm{P} 29 \mathrm{mtC} 3 \mathrm{H})$. 
Table 2

Evolutionary conservation of the polymorphic mutations found in mtDNA from P29mtC3H cybrids.

\begin{tabular}{rccccc}
\hline Species & Accetion No. & ND2 & COX3 & ND5 & D-loop \\
\hline C57BL/6J & AY172335 & FFYTRLI & VDVVWLF & IMQFSSW & ttaaac--taa \\
C3H/He & AB049357 & FFYTRLI & VDVIWLF & IMQFSSW ttaaac--taa \\
P29mtB6 & AP013030 & FFYTRLI & VDVVWLF & IMQFSSW ttaaat--taa \\
P29mtC3H & AP013031 & FFYIRLI & VDVIWLF & IMQLSSW ttaaac--taa \\
Homo sapiens & NC_012920 & YFYLRLI & VDVVWLF & IMEFSLW & cccacccttaa \\
Xenopus laevis & NC_001573 & FFYLRLT & VDVVWLF & ILEFATW & tgtaactttaa \\
Danio rerio & AC024175 & FFYLRLC & VDVVWLF & ILEFASW & tgtattatca- \\
Ciona savignyi & AB079784 & VFYSRTM & VDVVWIF & ILNFAQW & - \\
Drosophila melanogaster & U37541 & FFYLRIC & VDVVWLF & VIFYSKE & - \\
Caenorhabditis elegans & X54252 & AFSFWLI & VDVVWLF & VLVFSTY & - \\
Saccharomyces cerevisiae & AJ011856 & - & LDVIWLF & - & - \\
\hline
\end{tabular}



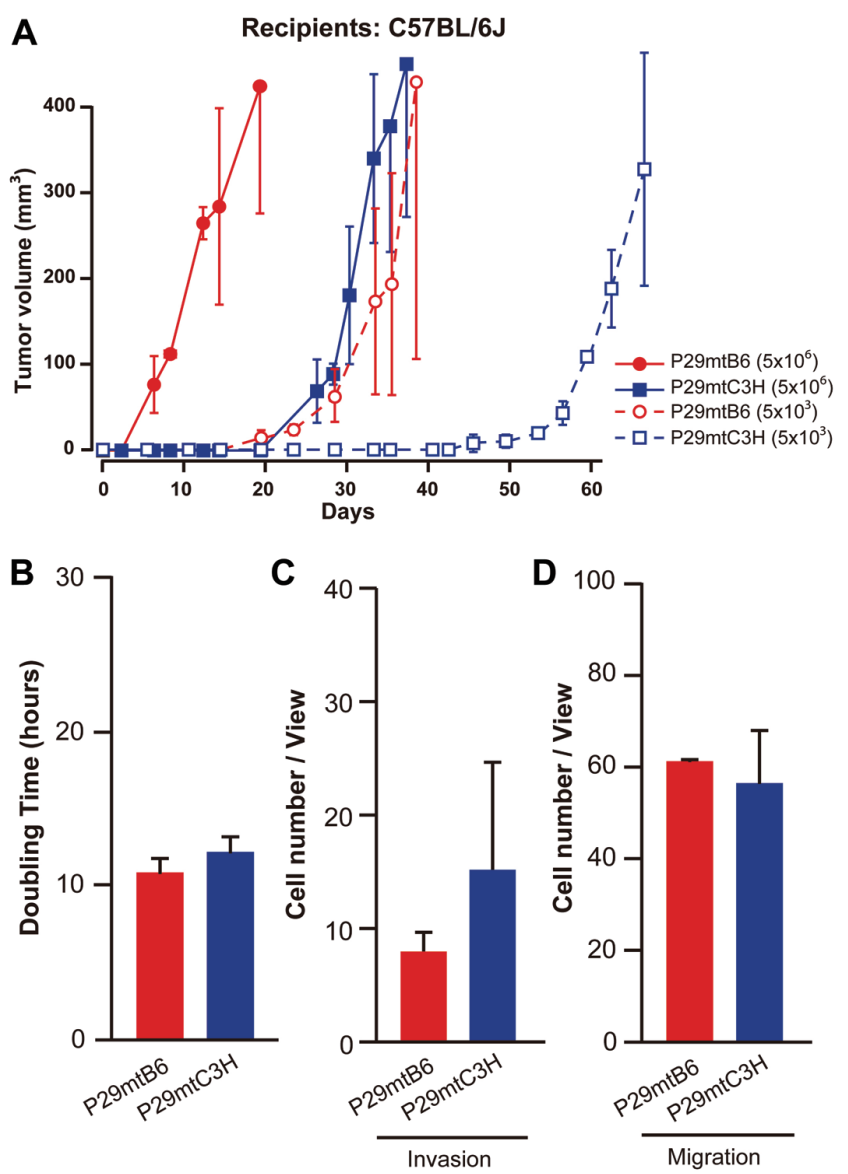

Fig. 1 

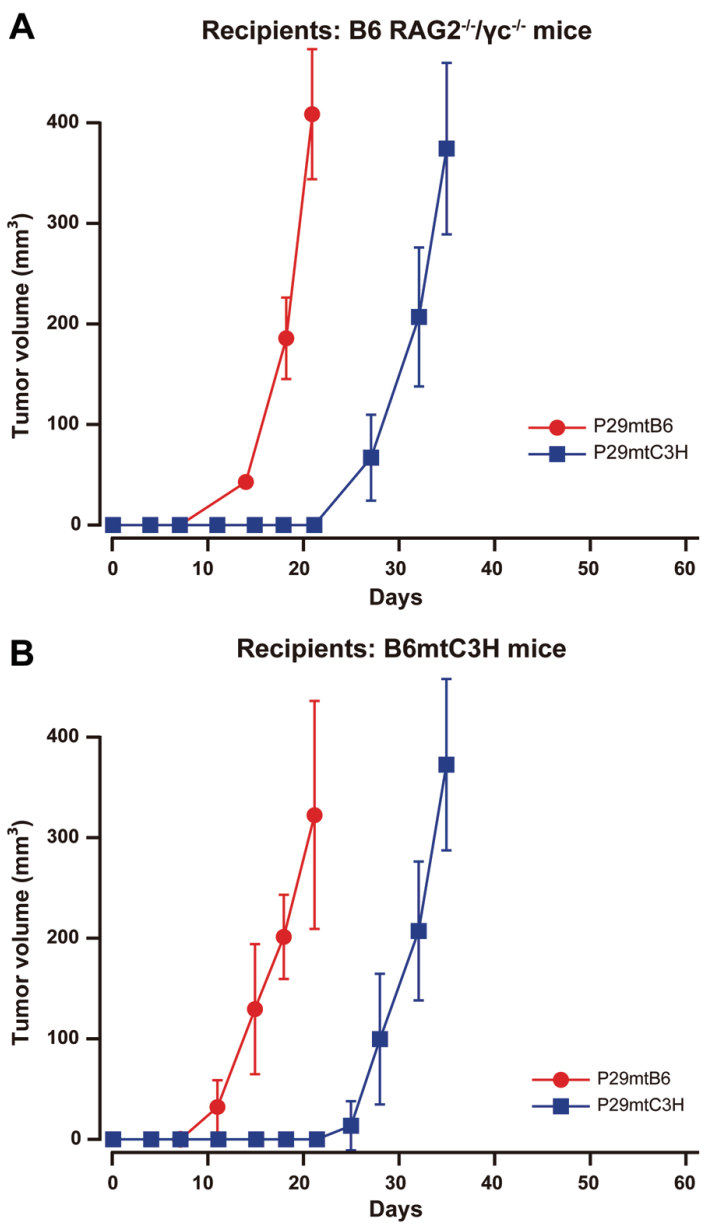

Fig. 2 

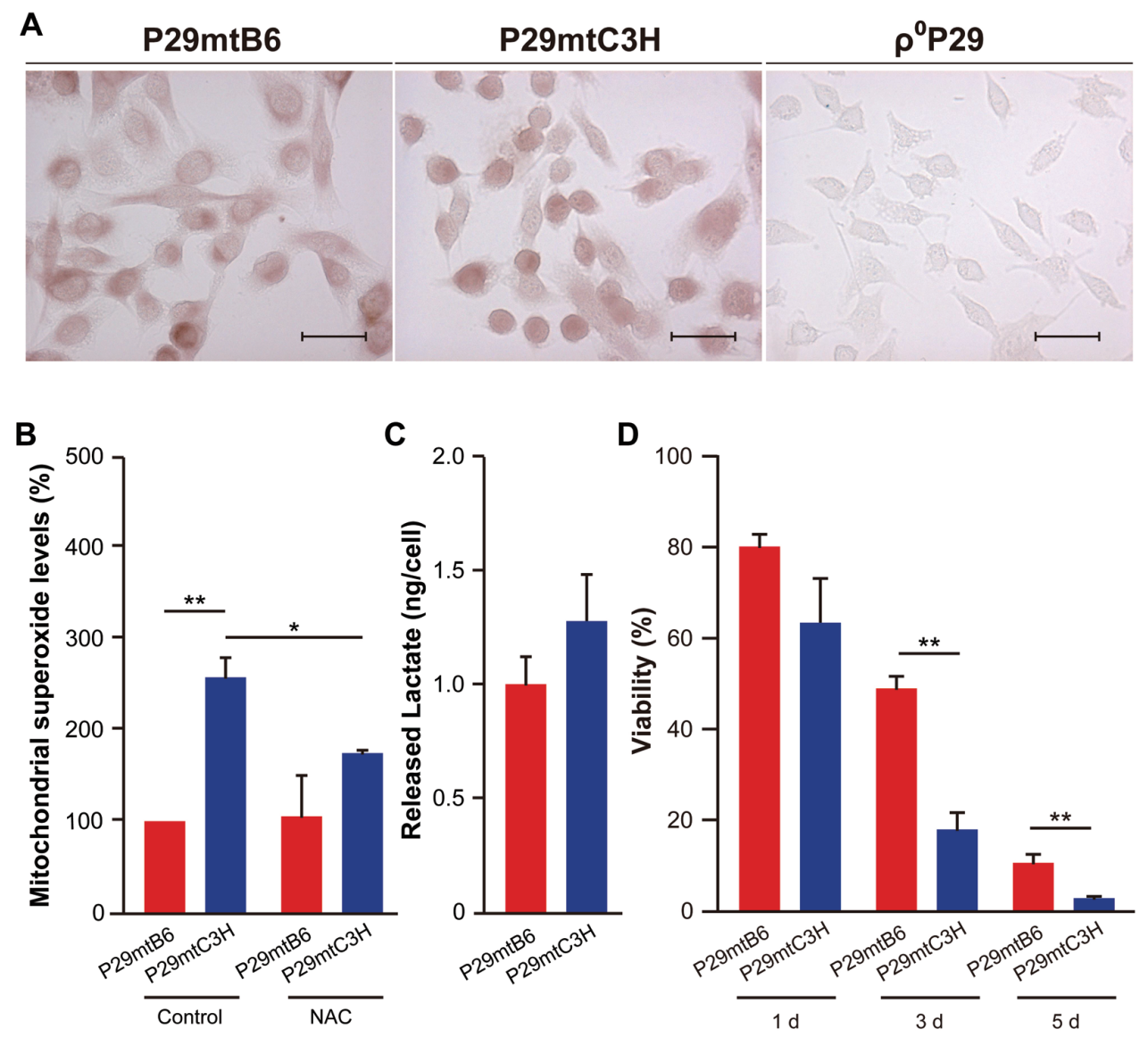

Fig. 3 

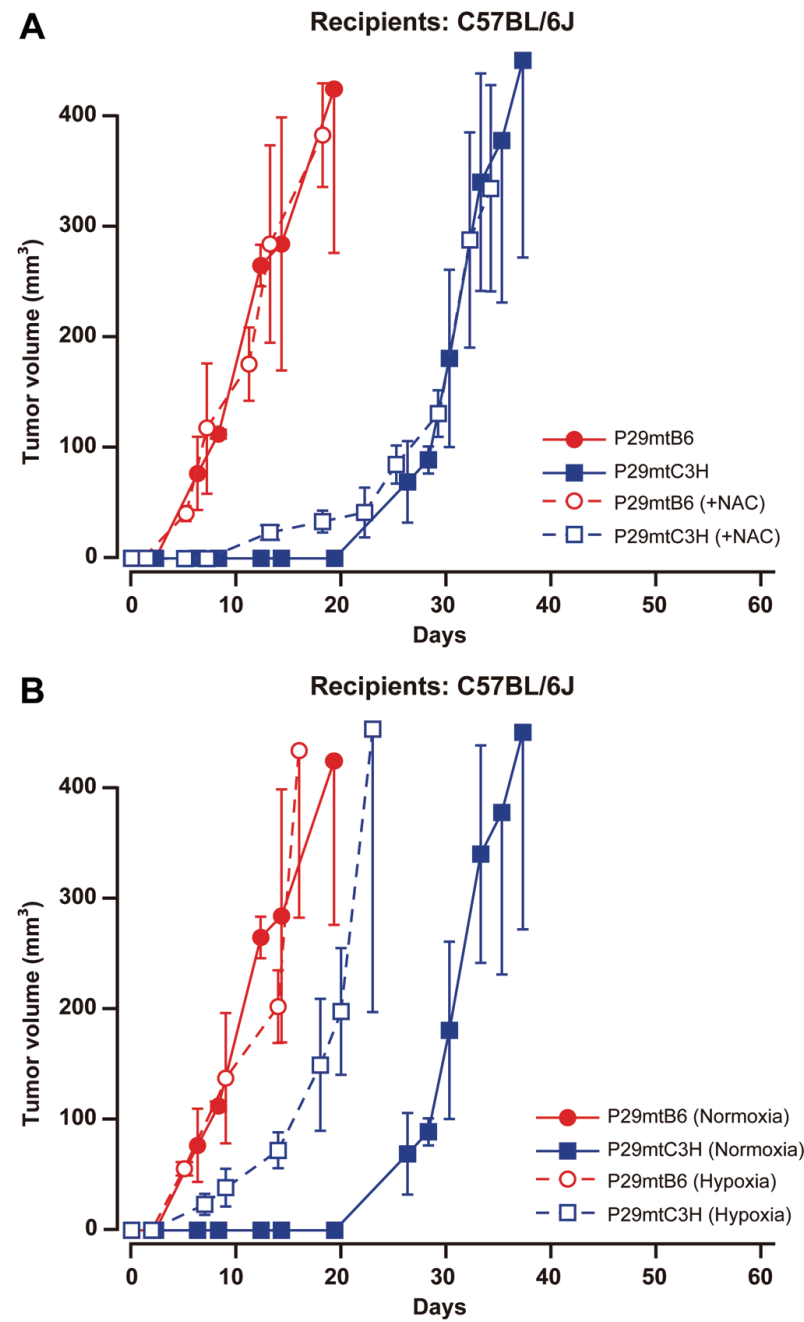

Fig. 4 


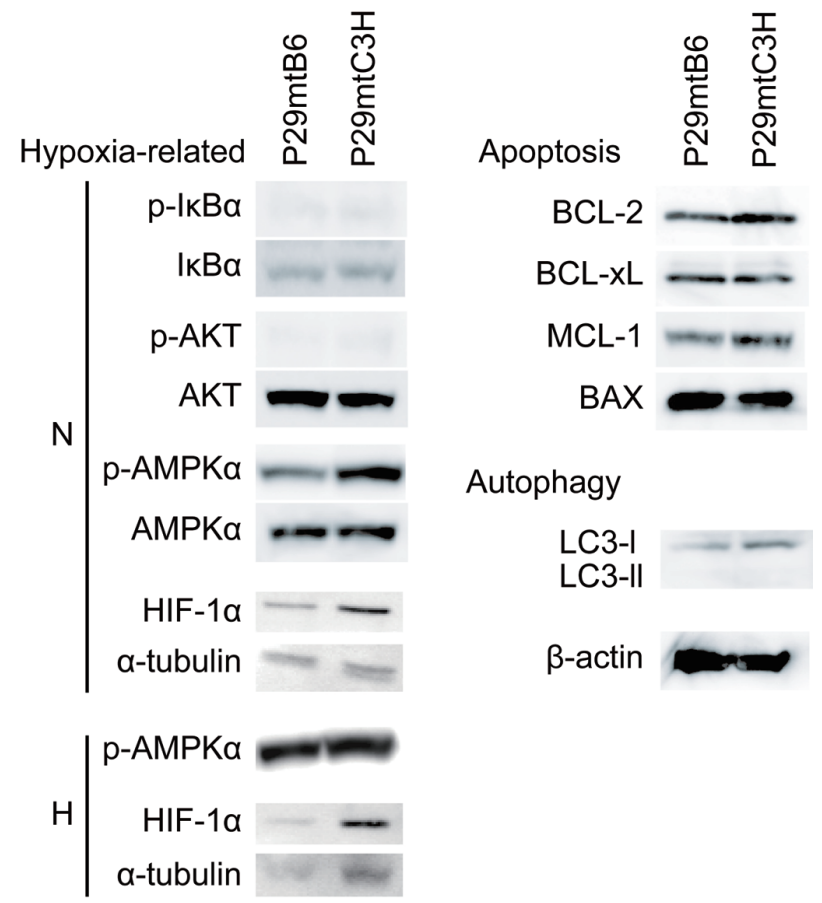

Fig. 5 


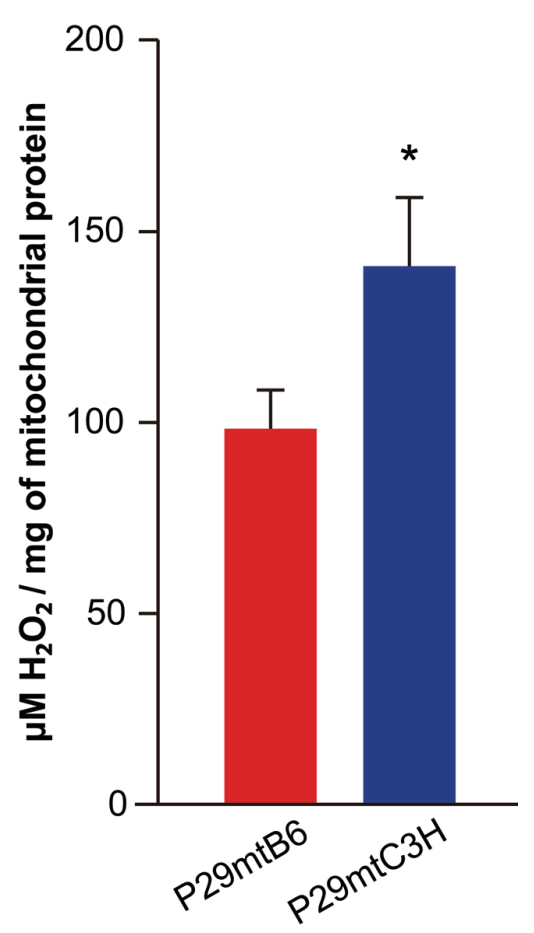

Fig. 51 